\title{
中下部進行直腸癌における肚門側直腸間膜内の リンパ節転移頻度と郭清効果における検討
}

\author{
須藤剛池田 栄一 佐藤 敏彦 \\ 山形県立中央病院外科
}

中下部進行直腸癌における直腸間膜内のリンパ節転移状況を明らかにし, 特に肛門側 mesorectum 内 のリンパ節転移状況とその郭清効果, さらに壁外進展様式 (Distal cancer spread: DCS) について検討し た. 検討 $1:$ 根治度 A, B の中下部直腸癌 189 例のうち腫瘍直下の mesorectum 内リンパ節を 251-1- $\mathrm{T}$, 腫 瘍から $5 \mathrm{~cm}$ 口側を 1-O，5〜10cm を 2-O, 腫痬から $2 \mathrm{~cm}$ 肛門側を 1-A，2〜 4cm 肛門側を 2-A とし，各リ ンパ節の転移頻度と 5 年生存率を乗じて郭清効果 Index を求めた. 検討 $2: 42$ 例の肛門側標本を $4 \mathrm{~mm}$ 幅に全割しDCSについて検討した。結果：検討 1 郭清効果は1-T はIndex がRa 18.1, Rab 24.3, Rb 28.3 と高值だが, 1-A は Ra 1.0, Rab 2.7, Rb 0 であり, 2-O や 252 に近い郭清効果を示した. 検討 2 DCS の頻度は $4.8 \%$ (2/42 例) でly であった。吻合部近傍に再発した 6 例中 4 例は肛門側進展例であった。考 察 : 現在 1 群とされている肚門側 $2 \mathrm{~cm}$ 以内のリンパ節は中枢側 2 群リンパ節に近い郭清効果であった. 分化型で限局型腫瘍は mesorectum を $2 \mathrm{~cm}$ 切除することで十分であり，上記以外では壁外進展を考慮し $2 \mathrm{~cm}$ 以上切除する必要があると思われた.

索引用語：直腸癌, 肛門側, 壁外進展, DCS, 郭清効果

直腸癌におけるリンパ節の転移状況は，予後や局 所再発に影響を及ぼす重要な因子の一つである。適 切なリンパ節の郭清範囲はリンパ節の転移頻度と予 後への影響に加え，それによって引きおこされる合 併症も考慮に検討すべきである，近年，中下部直腸 癌に対する標準的治療として, 器械吻合の導入や, 全身栄養面の改善から, 括約筋機能温存手術が普及 してきている. しかし, 直腸癌の局所再発率は施設 間において差は認めるものの, 約 $5 \sim 15 \%$ と少なく なく ${ }^{1)}$, 術式の適応においては癌の根治性と術後機 能の温存を考慮した上で検討すべきとされている. 大腸癌取扱い規約第 6 版で 1 群とされているリンパ 節転移陽性例のうちでも, 肛門側壁外 (mesorectum 内）リンパ節転移陽性例では局所再発率も高くそれ らの症例の予後は不良である. 腫瘍細胞の肛門側進 展形式が明らかになりつつあるが, 肚門側リンパ節 転移様式や, 郭清効果については必ずしも十分な検 討がなされていない. 今回我々は, 肚門側壁外リン パ節について, 存在状況と, 転移例の臨床病理学的 特徵, 郭清効果について検討し, さらに肛門側壁外
の癌細胞の進展 (Distal cancer spread : DCS) につい て検討した。

\section{対象と方法}

\section{検討 1}

対象症例：1991 年から 1998 年に山形県立中央病 院外科で自律神経温存の低位前方切除術または, 腹 会㓌式直腸切断術を施行し, 肛門側リンパ節が検出 可能であった根治度 A, B の直腸進行癌 189 例（Ra 99 例, Rab 37 例, Rb 53 例）とした.

方法 : 切除標本は術後速やかに, 腫瘍の壁在と対 側にて腸管を腸管軸に沿って開き，腸間膜脂肪組織 よりリンパ節を摘出した，直腸癌の壁在リンパ節を 以下のように分類した. 腫瘍直下を 251-1-T, 腫瘍よ り $5 \mathrm{~cm}$ 口側を 251-1-O, さらに $10 \mathrm{~cm}$ までを 251-2$\mathrm{O}$ とし，腫瘍より $2 \mathrm{~cm}$ 肛門側を251-1-A，さらに 4 $\mathrm{cm}$ までを 251-2-A と分類した (Fig. 1). 各占拠部位 別のリンパ節転移状況と, 肛門側リンパ節転移陽性 例の臨床病理学的検討を行い, さらに各リンパ節の 郭清の重みとして, 郭清効果をインデックスにして 


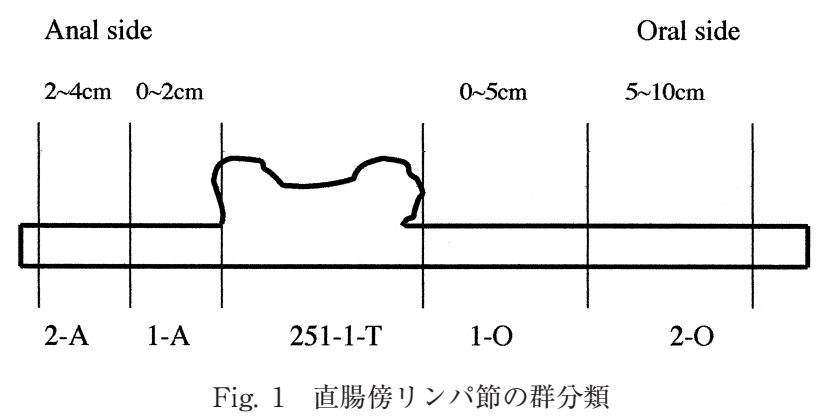

求めた．郭清効果は腫瘍の占拠部位ごとのリンパ節 部位別転移頻度と, 転移を認めた症例の 5 年生存率 を乗じて計算した５年生存率は他部位へのリンパ 節転移を認めたすべての症例を対象とした。早期直 腸癌はリンパ節の転移頻度が低いため除外した22.

\section{検討 2}

対象症例：1999 年から 2001 年までに当科で自律 神経温存の低位前方切除術または, 腹会陰式直腸切 断術を施行された根治度 A または B の直腸進行癌 42 例（Ra 24 例, Rab 12 例, Rb 6 例）とした.

方法 : 切除標本は術後速やかに, 直腸前壁にて腸 管を腸管軸に沿って開き，腫瘍より口側の腸間膜脂 肪組織よりリンパ節を摘出した。腫瘍直下より肛門 側の腸間膜脂肪組織はそのままとし，木板に新鮮標 本の形状にて打ち付け約 48 時間 10\% ホルマリン液 にて固定した。腫瘍より肛門側の腸管を長軸方向に 約 $4 \mathrm{~mm}$ 間隔にて全割し(Fig. 2), 直腸間膜内の DCS の進展について検討した.

組織学的分類および検定項目についての記載は大 腸癌取扱い規約第 6 版に基ついた。統計学的解析ソ フトはJUMPにより, 2 群間の差の検定には $\chi^{2}$ 検定 を用い, $\mathrm{p}<0.05$ をもって有意差ありとした. 生存率 は Kaplan-Meier 法にて算出した.

\section{結 果}

\section{検討 1}

\section{1 転移状況}

進行直腸癌 189 例中, リンパ節転移陽性例は 94 例 $(49.7 \%)$ であり，1 群リンパ節転移例は 51 例， 2 群リンパ節転移例は 20 例, 3 群リンパ節転移例は 12 例であった。そのうち肛門側リンパ節転移陽性例は 12 例 $(6.3 \%)$ であった. 施行された術式の肛門側切 除断端距離の中央值は Ra が $3.9 \mathrm{~cm} （ 1.0 \mathrm{~cm} \sim 7.5$ $\mathrm{cm}), \quad R a b 2.9 \mathrm{~cm}(1.0 \sim 5.2 \mathrm{~cm}), \quad \mathrm{Rb} 1.9 \mathrm{~cm}(1.0 \mathrm{~cm} \sim$
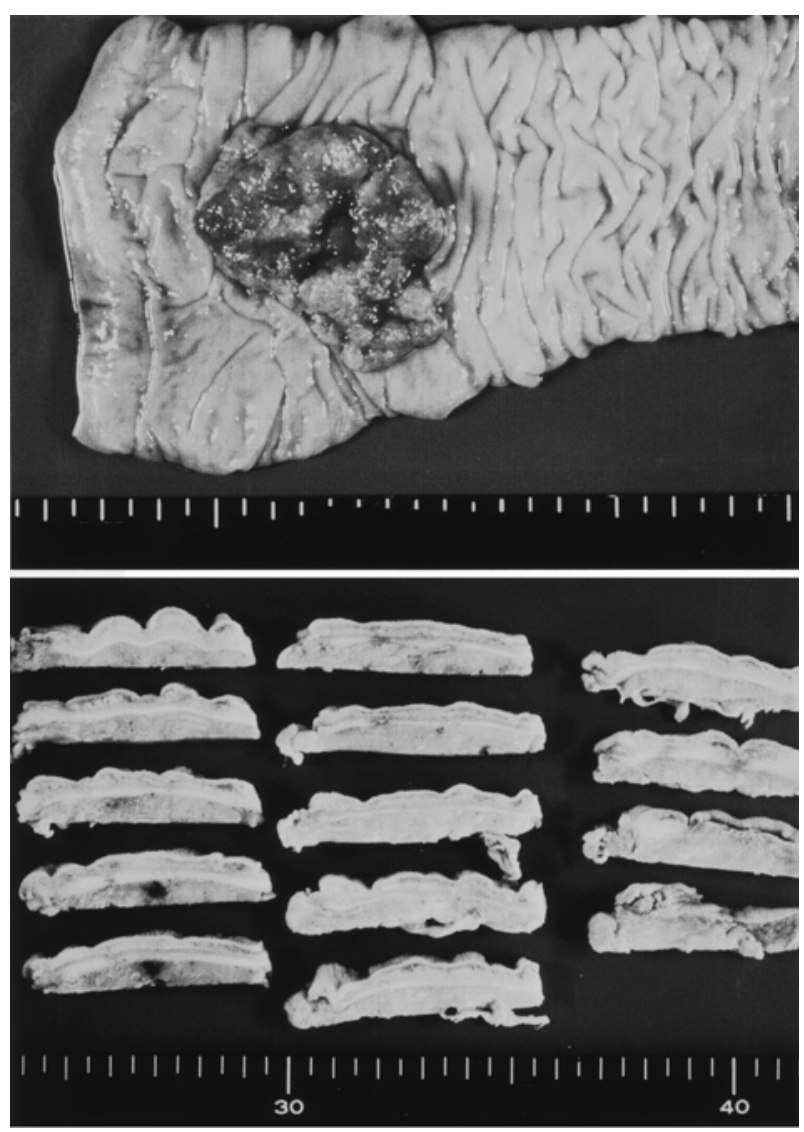

Fig. 2 直腸切除標本と肛門側の約 $4 \mathrm{~mm}$ 幅の全割標本 腫瘍直下より肛門側の腸間膜脂肪組織はそのままとし, 木板に新 鮮標本の形状にて固定後, 腫瘍より肛門側の腸管を約 $4 \mathrm{~mm}$ 幅に て全割した。

$4.8 \mathrm{~cm})$ であった. 各占拠部位別のリンパ節の郭清個 数は中央值で Ra 41 個 (18〜 78 個), Rab 39 個 (17〜 85 個), Rb 38 個（16〜69 個）であった.

各占拠部位別の肛門側リンパ節の存在頻度は Ra の 251-1-A は 83 例 $(83 \%), 251-2-\mathrm{A}$ の郭清例は 68 例でそのうちの 33 例 $(48.5 \%)$ が検出可能であり, Rabの 251-1-A は 18 例 (48.6\%), 251-2-A の郭清例 は 16 例でそのうち 2 例 (12.5\%) が検出可能であっ た. Rbの 251-1-A は 12 例 (22.6\%), 251-2-A の郭清 例は 12 例でありそのうち 2 例 $(16.7 \%)$ に検出可能 であったが，下部直腸になるに従い存在頻度は低下 した。ささに転移頻度は Ra の 251-1-A は 99 例中 8 例 (8.1\%)，251-2-A は 68 例中 1 例 (1.5\%)であった. $\mathrm{Rab}$ の 251-1-A は 37 例中 2 例 (5.4\%), 251-2-A は 16 例中 1 例 $(6.2 \%), \mathrm{Rb}$ の 251-1-A は 53 例中 2 例 $(3.7 \%)$ ，251-2-A は 12 例中 0 例 $(0 \%)$ であった (Table 1).

2 臨床病理学的検討 
Table 1 各リンパ節の存在率と転移率

\begin{tabular}{|c|c|c|c|c|c|c|}
\hline & $\mathrm{Ra}(\mathrm{n}=99)$ & $(\mathrm{n}=68)$ & $\operatorname{Rab}(\mathrm{n}=37)$ & $(\mathrm{n}=16)$ & $\mathrm{Rb} \quad(\mathrm{n}=53)$ & $(\mathrm{n}=12)$ \\
\hline & 251-1-A & 251-2-A & $1-A$ & $2-\mathrm{A}$ & $1-\mathrm{A}$ & $2-\mathrm{A}$ \\
\hline 存在率 & $83(83 \%)$ & $33(48.6 \%)$ & $18(48 \%)$ & $2(12.5 \%)$ & $12(22.6 \%)$ & $2(16.7 \%)$ \\
\hline 転移率 & $8(8.1 \%)$ & $1(1.5 \%)$ & $2(5.4 \%)$ & $1(6.2 \%)$ & $2(3.7 \%)$ & $0(0 \%)$ \\
\hline
\end{tabular}

Table 2 肛門側リンパ節転移の有無別の臨床病理学的背景

\begin{tabular}{|c|c|c|c|c|c|c|c|}
\hline & $\begin{array}{l}\text { Negative } \\
(\mathrm{N}=177)\end{array}$ & $\begin{array}{c}\text { Positive } \\
(\mathrm{N}=12)\end{array}$ & $\mathrm{P}$ 值 & & $\begin{array}{l}\text { Negative } \\
(\mathrm{N}=177)\end{array}$ & $\begin{array}{l}\text { Positive } \\
(\mathrm{N}=12)\end{array}$ & P 值 \\
\hline \multicolumn{4}{|l|}{ Gender } & \multicolumn{4}{|l|}{ Depth } \\
\hline Male & 99 & 7 & 0.9156 & $\mathrm{mp}$ & 32 & 0 & \\
\hline Female & 78 & 5 & & ss (a1) & 39 & $0-$ & 0.0317 \\
\hline \multicolumn{4}{|l|}{ Location } & se $(\mathrm{a} 2)$ & 98 & 11 & \\
\hline $\mathrm{Ra}$ & 91 & 8 & \multirow{3}{*}{0.3006} & si（ai） & 7 & 1 & \\
\hline Rab & 35 & 2 & & \multicolumn{4}{|c|}{ Lymphatic invasion } \\
\hline $\mathrm{Rb}$ & 51 & 2 & & $(-)$ & 105 & 1 & 0.0006 \\
\hline \multicolumn{4}{|l|}{ Tumor type } & $(+)$ & 72 & 11 & \\
\hline 1 & 23 & 0 & \multirow{3}{*}{0.0001} & \multicolumn{4}{|c|}{ Vernous invasion } \\
\hline 2 & 140 & 5 & & $(-)$ & 139 & 6 & 0.0366 \\
\hline 3 & 14 & 7 & & $(+)$ & 38 & 6 & \\
\hline \multicolumn{4}{|l|}{ 周径 } & \multicolumn{4}{|l|}{$\mathrm{n}$} \\
\hline$<2 / 3$ & 60 & 7 & & 1 & 55 & 4 & \\
\hline 亜全周 & 61 & 4 & 0.0580 & 2 & 16 & 4 & \\
\hline 全周 & 56 & 1 & & 3 & 8 & 4 & \\
\hline \multicolumn{4}{|c|}{ Tumor differenciation } & \multicolumn{4}{|l|}{ Stage } \\
\hline other & 8 & 6 & & 1 & 28 & 0 & \\
\hline wel & 125 & 5 & 0.0115 & 2 & 51 & 0 & \\
\hline $\bmod$ & 38 & 67 & & 3a & 52 & 4 & \\
\hline \multirow[t]{2}{*}{ por } & 6 & 1 & & $3 b$ & 23 & 8 & \\
\hline & & & & 4 & 4 & 0 & \\
\hline
\end{tabular}

肛門側リンパ節転移陰性例と陽性例において男性 は陰性例 106 例，陽性例 7 例，女性は各々 78 例と 5 例であった。肉眼型は院性例の限局型は（1 型， 2 型） 163 例 $(92.1 \%)$, 浸潤型 (3 型) 14 例 $(7.9 \%)$ で あり，陽性例は限局型 7 例 $(58.3 \%)$ ，浸潤型 5 例 (41.7\%) と浸潤型が多く認められた。周径は陰性例 で $2 / 3$ 周 以下 60 例 $(33.9 \%)$ ，亜 全 周 性 61 例 $(34.5 \%)$ ，全周性 56 例（31.6\%）で, 陽性例は各々 7 例 $(58.4 \%), 4$ 例 (33.3\%), 1 例 (8.4\%) であった. 組織型別にみると院性例は，高分化型 119 例 (67.2\%)，中分化型 38 例 $(21.5 \%)$ ，低分化型 12 例 (6.8\%)であり，陽性例では，高分化型 5 例 (41.7\%), 中分化型 6 例 $(50 \%)$, 低分化型 1 例 $(8.3 \%)$ と分化 度が低くなる傾向にあった，深達度別に見ると陰性 例では mp32 例 $(18.1 \%)$, ss（a1）39 例 $(22.0 \%)$, se（a2） 98 例 (55.4\%), ai7 例（4.5\%）であるが, 陽性例は全例 se（a2）以深であった。脈管侵襲にお いて, リンパ管侵襲 (ly) は陰性例において (-) 105
例 $(59.3 \%),(+) 72$ 例 $(40.7 \%)$ ，陽性例は（－）1 例 $(6.8 \%),(+) 11$ 例 $(93.2 \%)$ であった. 静脈侵襲 （v）は陰性例において ( - ) 139 例 $(78.5 \%),(+) 38$ 例 $(21.5 \%)$ ，陽 性 例は $(-) 6$ 例 $(50 \%),(+) 6$ 例（50\%）であり，脈管侵襲を高度に認める傾向に あった，統計学的にも肉眼型, 組織型, 深達度, 脈 管侵襲において有意差を認めていた。リンパ節転移 状況は, 肛門側リンパ節陰性例のうち $\mathrm{n} 0$ は 98 例 (55.3\%)，n1 55 例（31.1\%)，n2 16 例（9.1\%）n3 8 例 $(4.5 \%)$ に対し，陽性例は $\mathrm{n} 1, \mathrm{n} 2, \mathrm{n} 3$ とも 4 例ず つとリンパ節転移程度も高度な症例を多く認めた (Table 2)。リンパ節転移程度（n 因子別にみた）別 の肛門側リンパ節転移陽性頻度は $\mathrm{n} 1$ 症例では 59 例中 4 例 $(6.7 \%)$ であり, $\mathrm{n} 2$ 症例では 20 例中 4 例 $(20 \%), \mathrm{n} 3$ 症例では 12 例中 4 例 $(33.3 \%)$ と n 因子 が高くなるにつれて肚門側リンパ節転移陽性頻度も 高率となった。さらに肛門側リンパ節転移陽性例の 1 群リンパ節転移様式は 251-1-A，Tと 2 領域にみ 
Table 3

\begin{tabular}{|c|c|}
\hline \multicolumn{2}{|c|}{ リンパ節転移程度別の肛門側リンパ節陽性頻度 } \\
\hline n1 & $6.7 \%$ (4/59 例) \\
\hline $\mathrm{n} 2$ & $20.0 \%(4 / 20$ 例 $)$ \\
\hline n3 & $33.3 \%(4 / 12$ 例 $)$ \\
\hline \multicolumn{2}{|c|}{ 肛門側リンパ節転移様式 } \\
\hline 251-1-A, T & 3 例 \\
\hline 251-1-A, T, O & 9 例 \\
\hline
\end{tabular}

Table 4 各リンパ節の占拠部位別の転移頻度

\begin{tabular}{lccccc}
\hline & $\begin{array}{c}\mathrm{Ra} \\
(\mathrm{N}=99)\end{array}$ & $\begin{array}{c}\mathrm{Rab} \\
(\mathrm{N}=37)\end{array}$ & $\begin{array}{c}\mathrm{Rb} \\
(\mathrm{N}=53)\end{array}$ & $\begin{array}{c}\text { Total } \\
(\mathrm{N}=189)\end{array}$ \\
\hline 253 & $2(2.0 \%)$ & $0(0 \%)$ & $1(0.8 \%)$ & $3(1.6 \%)$ \\
252 & $9(9.1 \%)$ & $4(1.1 \%)$ & $4(7.5 \%)$ & $17(8.9 \%)$ \\
$251-2-\mathrm{O}$ & $3(3.3 \%)$ & $6(16.2 \%)$ & $11(20.7 \%)$ & $20(10.5 \%)$ \\
$251-1-\mathrm{O}$ & $20(20.2 \%)$ & $15(40.5 \%)$ & $21(39.6 \%)$ & $56(29.6 \%)$ \\
$251-1-\mathrm{T}$ & $35(35.3 \%)$ & $15(40.5 \%)$ & $25(47.2 \%)$ & $75(39.6 \%)$ \\
$251-1-\mathrm{A}$ & $8(8.1 \%)$ & $2(5.4 \%)$ & $2(3.8 \%)$ & $12(6.3 \%)$ \\
\hline
\end{tabular}

Table 5 各リンパ節の占拠部位別転移陽性例の 5 年生存率

\begin{tabular}{lcccc}
\hline & $\begin{array}{c}\mathrm{Ra} \\
(\mathrm{N}=99)\end{array}$ & $\begin{array}{c}\mathrm{Rab} \\
(\mathrm{N}=37)\end{array}$ & $\begin{array}{c}\mathrm{Rb} \\
(\mathrm{N}=53)\end{array}$ & $\begin{array}{c}\text { Total } \\
(\mathrm{N}=189)\end{array}$ \\
\hline 253 & 50.0 & 0 & 0 & 33.3 \\
252 & 11.1 & 25.0 & 16.7 & 21.3 \\
$251-2-\mathrm{O}$ & 33.3 & 16.7 & 54.5 & 18.1 \\
$251-1-\mathrm{O}$ & 40.0 & 33.3 & 52.4 & 47.6 \\
$251-1-\mathrm{T}$ & 51.4 & 53.3 & 60.0 & 57.1 \\
$251-1-\mathrm{A}$ & 25.0 & 50.0 & 0 & 25.0 \\
\hline
\end{tabular}

られる例が 3 例，251-1-A，T，Oの 3 領域にみられ る例が 9 例であり, 肚門側リンパ節だけが陽性の例 は認めなかった（Table 3).

\section{3 郭清効果}

各腫瘍の占拠部位別のリンパ節の転移頻度を Table 4 に示した. 251-1-T は Ra 35.3\%, Rab 40.5\%, Rb $47.1 \%$ と高頻度であったが, 肚門側リンパ節のうち, 251-1-A は, Ra 8.1\%, Rab 5.4\%, Rb 3.8\% と少なかっ た. 次に腫瘍占拠部位別のリンパ節の 5 年生存率を Table 5 に示した. 251-1-T 陽性例の生存率は Ra $51.4 \%$, Rab 53.3\%, Rb 60.0\% と良好であるが, 肛門 側リンパ節陽性例の生存率は Ra 25.0\%, Rab 50\%, $\mathrm{Rb} 0 \%$ と低值であった，さらに両者を乗じた值を郭 清効果インデックスとし Table 6 に示した. 251-1$\mathrm{T}$ の陽性例のインデックスは Ra 18.1, Rab 21.6, Rb 28.3 と高值であったが, 251-1-A 陽性例では, Ra
Table 6 各リンパ節の郭清効果インデックス

\begin{tabular}{lcccc}
\hline & $\begin{array}{c}\mathrm{Ra} \\
(\mathrm{N}=99)\end{array}$ & $\begin{array}{c}\text { Rab } \\
(\mathrm{N}=37)\end{array}$ & $\begin{array}{c}\mathrm{Rb} \\
(\mathrm{N}=53)\end{array}$ & $\begin{array}{c}\text { Total } \\
(\mathrm{N}=189)\end{array}$ \\
\hline 253 & 1.0 & 0 & 0 & 0.5 \\
252 & 1.0 & 2.7 & 1.2 & 1.9 \\
$251-2-\mathrm{O}$ & 1.0 & 2.7 & 1.2 & 1.9 \\
$251-1-\mathrm{O}$ & 8.1 & 13.4 & 20.7 & 14.1 \\
$251-1-\mathrm{T}$ & 18.1 & 21.6 & 28.3 & 22.6 \\
$251-1-\mathrm{A}$ & 2.0 & 2.7 & 0 & 1.6 \\
\hline
\end{tabular}

各リンパ節の占拠部位別の転移頻度 $=$ A（\%)

各リンパ節の占拠部位別転移陽性例の 5 年生存率 = B (\%)

郭清効果インデックス $=\mathrm{A} \times \mathrm{B} / 100$
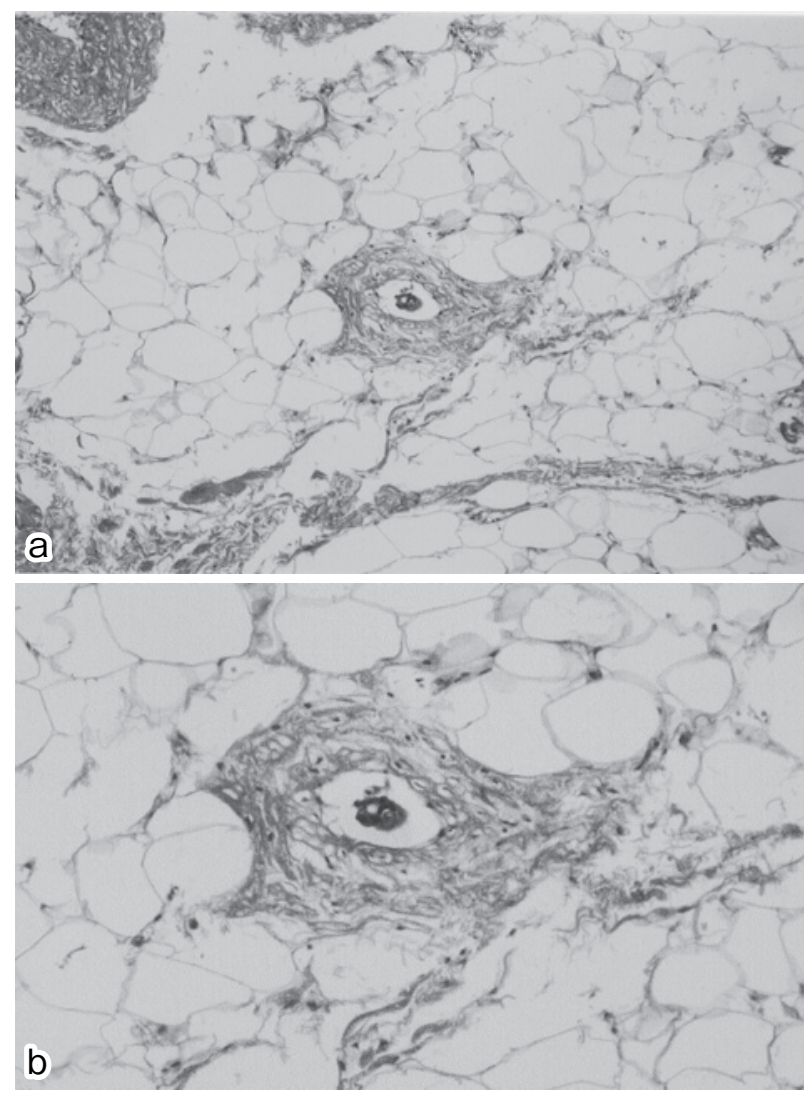

Fig. 3 肛門側腸間膜脂肪組織内のリンパ管侵襲 Hematoxylin and eosin; $\mathrm{a} \times 10 / \mathrm{b} \times 50$

2.0, Rab 2.7, Rb0であり, このインデックス值は 251-2-O や 252 陽性例のインデックスに近く中枢側 2 群リンパ節の郭清効果と同等であった。

\section{検討 2}

DCS の頻度は $4.8 \%(2 / 42$ 例) であり， 2 例ともに リンパ管侵襲であった（Fig. 3a, b). 各々の臨床病 理学的特徵は 2 例ともに占拠部位は Rab で肉眼型 は浸潤型であり, 組織型は各々中分化型と低分化型 腺癌であった。中枢側リンパ節転移は各々 2 群, 3 
群リンパ節転移陽性で転移個数も 17 個と 15 個と高 度の例であった. さらに腫瘍の肛門側から DCS まで の距離は $24 \mathrm{~mm}$ と $10 \mathrm{~mm}$ であった（Table 7, 8).

\section{局所再発}

検討 1 の対象例 189 例のうち局所再発例は肛門側 リンパ節転移が陽性であった 2 例を含めた 10 例で $5.2 \%$ であった，その内訳を見ると吻合部近傍再発が 4 例, 腸骨リンパ節再発が 2 例, 仙骨前面再発が 4 例 であった. 検討 2 の対象症例のうち DCS 陽性例の 2 例はいずれも吻合部近傍再発を認めた（Table 9).

Table 7 肛門側標本全割例の臨床病理学的背景

\begin{tabular}{|c|c|}
\hline \multicolumn{2}{|l|}{ Gender } \\
\hline Age year mean (range) & $68(37 \sim 89)$ \\
\hline \multicolumn{2}{|l|}{ Location } \\
\hline $\mathrm{Ra} / \mathrm{Rab} / \mathrm{Rb}$ & $24 / 12 / 6$ \\
\hline \multicolumn{2}{|l|}{ Tumor type } \\
\hline $1 / 2 / 3$ & $6 / 31 / 5$ \\
\hline $\begin{array}{l}\text { Tumor differenciation } \\
\text { well } / \bmod / \text { por }\end{array}$ & $36 / 5 / 1$ \\
\hline \multicolumn{2}{|l|}{ Lymphatic invasion } \\
\hline \multicolumn{2}{|l|}{ Vernous invasion } \\
\hline \multicolumn{2}{|l|}{ depth } \\
\hline \multicolumn{2}{|l|}{$\mathrm{pN}$} \\
\hline $\mathrm{n} 0 / \mathrm{n} 1 / \mathrm{n} 2 / \mathrm{n} 3 / \mathrm{n} 4$ & $24 / 10 / 7 / 0 / 1$ \\
\hline \multicolumn{2}{|l|}{ Stage } \\
\hline $\mathrm{I} / \mathrm{II} / \mathrm{III} / \mathrm{IIIb} / \mathrm{IV}$ & $6 / 19 / 10 / 6 / 1$ \\
\hline \multicolumn{2}{|l|}{ Operative procedure } \\
\hline $\begin{array}{l}\text { Low anterior resection/ } \\
\text { abdominoperineal resection }\end{array}$ & $40 / 2$ \\
\hline $\begin{array}{l}\text { The length of distal margin }(\mathrm{cm}) \\
\text { mean (range) }\end{array}$ & $3.8(1.5 \sim 7.0)$ \\
\hline
\end{tabular}

\section{考察}

直腸癌のリンパ節郭清は上腸間膜動脈の根部に向 かう上方向, 中直腸動脈, 下直腸動脈から内腸骨動 脈に向かう側方向, 坐骨直腸窩を通過し, 鼠径リン パ節に向かう下方向の 3 方向のリンパ流に基づいて 施行されている ${ }^{3)}$. リンパ節の転移状況は, 予後や局 所再発の重要な因子の一つであり, 適切なリンパ節 の郭清範囲の決定には転移頻度と予後への影響, さ らにそれによって引きおこされる合併症を含めて考 慮されるべきである，局所再発の原因の一つには手 術操作 (implantation) による直腸癌腫瘍下縁より肚 門側 mesorectum 内の転移リンパ節や, 癌細胞など の遺残が考えられている. 欧米では Healdらにより mesorectum を完全切除する TME（Total mesorectal excision) が提唱され，その後 $20 \%$ を越えていた 局所再発率も $5 \%$ まで低下したが ${ }^{4.5)}$, 縫合不全率も 増加することが報告されている6 ${ }^{6}$. 今回我々は腫瘍 下縁より肚門側における mesorectum 内の各リン パ節の転移率とその重みを郭清効果として検討し た。肛門側 mesorectum 内のリンパ節転移率につい

Table 8 DCS 陽性例の臨床病理学的背景

\begin{tabular}{lcc}
\hline Patient No & 1 & 2 \\
Operation procedure & LAR & LAR \\
Tumor location & Rab & Rab \\
Tumor type & invasive & invasive \\
Tumor differenciation & por & mod \\
$\mathrm{n}$ & 2 & 4 \\
Lymphatic invasion & positive & positive \\
Vernous invasion & positive & posotive \\
Disatal spread (mm) & 24 & 10 \\
Mode of distal spread & lymphatic & lymphatic \\
& space & space \\
Outcome after initial operation & LR & LR \\
\hline
\end{tabular}

LAR : low anterior resection, LR : local recurrence

Table 9 吻合部近傍再発例

\begin{tabular}{ccccccc}
\hline No & Location & Tumor type & Tumor differenciation & AW & $\mathrm{n}$ & others \\
\hline 1 & $\mathrm{Ra}$ & 2 & $\bmod$ & 2.2 & $\mathrm{n} 2$ & $251-1-\mathrm{A}(+)$ \\
2 & $\mathrm{Ra}$ & 3 & $\bmod$ & 2.5 & $\mathrm{n} 3$ & $251-1-\mathrm{A}(+)$ \\
3 & $\mathrm{Rab}$ & 3 & $\bmod$ & 1.5 & $\mathrm{n} 4$ & DCS $(+)$ \\
4 & $\mathrm{Rab}$ & 3 & por & 3.1 & $\mathrm{n} 2$ & DCS $(+)$ \\
5 & $\mathrm{Rab}$ & 2 & wel & 1.5 & $\mathrm{n} 1$ & - \\
6 & $\mathrm{Rab}$ & 3 & $\bmod$ & 1.2 & $\mathrm{n} 0$ & - \\
\hline
\end{tabular}

AW : cm 
て Grinnell らは $4.2 \%$ に, Williams は $6 \%$ の症例に, Raynold は壁深達度 ss (a1) 以深の症例の $52 \%$ にリ ンパ節転移を認めていたと報告している. ${ }^{7-9)}$. 本邦 でも肥田らは $20.2 \%$ のリンパ節転移を報告してい る ${ }^{10)}$. 今回の検討では肛門側のリンパ節の存在頻度 は Ra から Rbへと下部直腸になるに従い 251-1-A, 2-A ともに減少していた，転移頻度も全体で $6.3 \%$ (12/189 例) であるが，占拠部位別に見ると Ra から Rbになるに従い，251-1-A，2-A ともに低下してい た.これは切除し得る mesorectum が少なくなるた めではないかと推測された。肛門側リンパ節転移陽 性例の臨床病理学的背景では肉眼型は浸潤型が多 く, 組織型も中低分化型腺癌と分化度が低い傾向に あった．壁深達度は全例 se（a2）以深で，ほとんど がリンパ管侵襲陽性例であり, 悪性度の高い癌と考 えられた. 白水らは肚門側の mesorectum 内のリン パ節転移は上腸間膜動脈に沿った中枢側へのリンパ 節転移が高度になると lymphatic flow が変化する ためと述べている ${ }^{11)}$. 今回の肍門側リンパ節転移陽 性例を $\mathrm{n}$ 因子別にみると $\mathrm{n}$ 因子が高くなるに従い 肛門側リンパ節転移陽性頻度も高くなっていた。さ らに肛門側リンパ節転移陽性例の 1 群リンパ節転移 様式は251-1-A， T と，251-1-A， T, O であり，すべ て複数領域にわたって転移のある例で, 肚門側リン パ節のみ陽性例は認めかった，予後において肚門側 mesorectum 内へのリンパ節転移例は, 不良である と報告されている ${ }^{8,11-13)}$. これらのことから, 直腸癌 の壁在リンパ節の中でも郭清による予後の改善への 重みが異なると考えられ, 各リンパ節の郭清効果を インデックスとして求めた. 郭清効果は腫痬の占拠 部位ごとのリンパ節転移頻度と, 転移症例の 5 年生 存率を乗じて計算することで, 各占拠部位において, 転移頻度が高く, 転移を認めた症例の 5 年生存率が 良いリンパ節は郭清効果が高いと考えられる。我々 の検討では, 251-1-T, 1-O はインデックスが高值で あるが, 1-A は各占拠部位別においても低值であり, そのインデックスは 251-2-O や, 252 と中枢側 2 群リ ンパ節に近い值であった. $\mathrm{Rb} の 2$ 例は中枢側のリン パ節転移も 2 群, 3 群転移陽性例で側方転移も認め ており, リンパ節転移個数も 13 個と 15 個と多く, 5 年生存率は $0 \%$ であり, 予後不良の症例であった。 この結果より大腸癌取扱い規約第 6 版において 1 群 とされている肚門側 $2 \mathrm{~cm}$ 以内のリンパ節は中枢側
2 群リンパ節に近い郭清効果と考えられた。

局所再発において肚門側断端の至適範囲は現在も 議論の対象となっているが, Scottらは腫瘍下縁か ら肚門側 $30 \mathrm{~mm}$ 以内の mesorectum 内に $20 \%$ の頻 度でDCSを認めている ${ }^{12)}$. Heald らは $40 \mathrm{~mm}$ 以内 に認めたと述べているが4), $30 \mathrm{~mm}$ 以上に認める症 例は非常に稀であると述べている. らは 7.5\%にリンパ節転移の形で肛門側 mesorectum 内にDCS を認めており, その最長距離は Madson $ら^{17)}$ による組織学的な計測法を用いて $24 \mathrm{~mm} の$ ため, 切除範囲は $3 \mathrm{~cm}$ 必要であると述べている. 直 腸癌の肚門側壁内進展は $85 \%$ には認められず18), 最大でも 10〜 20mm 以内といわれており ${ }^{10.15)}$, 壁外 進展の方が壁内進展よりもより遠位に進展するとも 述べられている ${ }^{12)}$. 肥田らはss（a1）以深の例では $\mathrm{Ra}$ では腸管壁を $3 \mathrm{~cm}$ 以上, mesorectum を $5 \mathrm{~cm}$ 以 上, $\mathrm{Rb}$ では腸管壁を $2 \mathrm{~cm}$ 以上, mesorectum は全切 除する必要があると述べている ${ }^{10)}$ また, 山口らは 局所再発と肛門側断端までの距離に相関関係は認め ないとも述べており ${ }^{19)}$, 切除範囲においては様々な 意見が有り, 厳密な数值は示されていない. 今回の 検討では, 検討 1 での転移リンパ節の腫瘍下縁から の距離は範囲のみでしか測定できていないが, 検討 2 において検討できた症例数は 42 例と少ないもの の 2 例にリンパ管侵襲の DCS を認め, 腫瘍下縁より 最長 $24 \mathrm{~mm}$ であった. これら 2 例も検討 1 の肛門側 リンパ節転移陽性例と同様に癌の悪性度が高く, 中 枢側リンパ節転移程度も高度であった。 その後吻合 部近傍再発を認め, さらに遠隔転移も出現し死亡し た. 検討 1 での局所再発率は $5.2 \%(10 / 189$ 例）で あった.これらのうち, 吻合部近傍再発例は 4 例で あり, 肛門側リンパ節 (251-1-A) 転移陽性例は 2 例 認めた.この 2 例の肛門側切除距離は $2.2 \mathrm{~cm}$ と 2.5 $\mathrm{cm}$ であり, 検討 2 における DCS 陽性例とともに肛 門側の切除範囲を考慮すべきであったと思われた。

以上より, Ra および Rabの直腸癌において分化 型で限局型腫瘍では mesorectum を $2 \mathrm{~cm}$ 切除する ことで十分と考えられた．上記以外の腫瘍において は mesorectum 内にリンパ節転移や DCS ともなう 症例も多く, 根治性の面から mesorectum $2 \mathrm{~cm}$ 以上は切除する必要があると考えられた. Rbにおい てはリンパ節が存在する率は少ないが, 直腸固有筋 膜を適切に切除すれば壁内浸潤を考慮した切除断端 
距離で良いと考えられた。

今後は直腸癌の局所再発を予防するための治療法 の確立とともに，肛門側リンパ節転移例の郭清効果 の重みと, DCS の可能性も考慮し術式を選択するべ きと思われる.

なお本論文の要旨は第 104 回日本外科学会定期学術集会 において発表した。

\section{文献}

1）松本 寛, 森 武生, 高橋慶一ほか：直腸癌局所再発の 現状；わが国と欧米との比較. 消化器外科 $29: 13-17$, 2006

2）笹子三津留, 佐野 武, 片井 均ほか：胃癌取り扱い規 約に扔けるリンパ節群分類の問題点. 手術 52:737743,1998

3）高橋 孝：直腸のリンパ路. 手術 40:1355-1365, 1991

4) Heald RJ, Husband EM, Ryall RD : The mesorectum in rectal cancer surgery-the clue to pelvic recurrence? $\mathrm{Br}$ J Surg 69 (10) : 613-616, 1982

5) McFarlane JK, Ryall RD, Heald RJ : Mesorectal excision for rectal cancer. Lancet 341 (8843) : 457-460, 1993

6) Law W, Chu K, Ho JWC, et al : Risk factors for anastomosis leakage after low anterior resection with total mesorectal excision. Am J Surg 179 : 92-96, 2000

7) Grinnell RS : Lymphatic metastases of carcinoma of the colon and rectum. Ann Surg 131 : 494-506, 1950

8) Williams NS, Dixon MF, Johnson D, et al : Reapraisal 5 centimetre rule of distal excision for carcinoma of the rectum : a study of distal intramural spread and of patient's survival. Br J Surg 70 : 150-154, 1983
9) Reynolds JV, Joyce WP, Dolan J, et al : Pathological evidence in support of total mesorectal excision in the management of rectal cancer. Br J Surg 83 : 1112-1115, 1996

10) Hida J, Yasutomi M, Maruyama T, et al : Lymph node metastasis detected in the mesorectum distal to carcinoma of the rectum by the clearing method : justification of total mesorectal excision. J Am Coll Surg 184 : 584-588, 1997

11) Shirouzu K, Isomoto $H$, Kakegawa $T$ : Distal spread of rectal cancer and optimal distal margin of resection for sphincter-preserving surgery. Cancer 76 : 388-92, 1995

12) Scott N, Jackson P, al-Jaberi T, Dixon MF, Quirke P, Finan PJ : Total mesorectal excision and local recurrence : a study of tumor spread in the mesorectum distal to rectal cancer. Br J Surg $82: 1031-3,1995$

13) Grinnel Rs : Lymphatic block with atypical retrograde lymphatic metastasis and spread in carcinoma of colon and rectum. Ann Surg 163:272-80, 1966

14）北條慶一ほか：直腸癌括約筋温存術後の再発一特に腫 瘍下縁より肚門側切除断端までの長さと関連して一. 日 外会雑誌 $85: 1537-1544,1984$

15）森田隆幸ほか：超低位前方切除の適応と成績. 外科治療 $69: 294-298,1993$

16) Ono $\mathrm{C}$, et al: Discontinuous rectal cancer spread in the mesorectum and the optimal distal clearance margin in situ. Dis colon Rectum 45 : 744-749, 2002

17) Madsen PM, Christiansen J : Distal intramural spread of rectal carcinomas. Dis colon Rectum 29 : 279-282, 1986

18) Kwork SPY, Law WY, Leung KL, et al : Prospective analysis of the distal margin of clearance in anterior resection for rectal carcinoma. Br J Surg 83 : 969-972, 1996

19）山口達郎, 森 武生, 高橋慶一ほか：大晹癌の Controversy一外科の立場から：直腸癌手術におけるリンパ節 郭清（側方郭清と TME）一. 癌と化学療法 30:12561259,2003 


\title{
Pathological Study of the Frequency of Metastasis and the Effectiveness of Lymphadenectomy of Lymph Nodes and the Distal Spread of Upper and Lower Rectal Cancer in Anal Side Mesorectum from Tumor
}

\author{
T. Suto, E. Ikeda, and T. Sato \\ Department of Gastroenterological Surgery, Yamagata Prefectual Central Hospital
}

The status of lymph node metastasis in rectal cancer is an important factor in predicting the prognosis and local recurrence.

Patients and methods : Evaluation 1 : In 189 patients with middle or lower rectal cancer at CurA or B, lymph nodes in the mesorectum below the tumor were classified as 251-1-T, those $5 \mathrm{~cm}$ to the oral side from the tumor as 10 , those $2 \mathrm{~cm}$ to the anal side as 1-A, and the lymphadenectomy index was calculated by multiplying the frequency of metastasis to lymph nodes in each region by the 5-year survival rate.

Evaluation 2 : Rectal samples on the anal side from 42 patients were sliced at an interval of $4 \mathrm{~mm}$, and distal cancer spread (DCS) was evaluated.

Results : Evaluation 1 : The lymphadenectomy index in 1-A was similar to those in 2-0 and 252.

Evaluation 2 : DCS was demonstrated in $4.8 \%(2 / 42)$ and was due to lymphatic invasion.

Discussion : The effectiveness of lymphadenectomy in lymph nodes within $2 \mathrm{~cm}$ to the anal side from the tumor, which are classified as Group 1, was close to that in proximal Group 2. Resection of 2 cm of the mesorectum appears to be sufficient for differentiated, limited tumors. 